\title{
DNA damage and repair in Arabidopsis thaliana as measured by the comet assay after treatment with different classes of genotoxins
}

\author{
Merten Menke ${ }^{\mathrm{a}}$, I-Peng Chen ${ }^{\mathrm{a}}$, Karel J. Angelis ${ }^{\mathrm{b}}$, Ingo Schubert ${ }^{\mathrm{a}, *}$ \\ a Institute of Plant Genetics and Crop Plant Research (IPK), Corrensstr. 3, D-06466 Gatersleben, Germany \\ ${ }^{\mathrm{b}}$ Institute of Experimental Botany, Academy of Science of the Czech Republic, Na Karlovce 1a, 16000 Prague 6, Czech Republic
}

Received 24 October 2000; received in revised form 27 February 2001; accepted 6 March 2001

\begin{abstract}
The three protocols of the comet assay A/N, A/A and N/N were for the first time applied to the plant species Arabidopsis thaliana. The purpose of the experiments was to establish conditions for genotoxic exposure causing DNA damage in Arabidopsis nuclei. This is required for comprehensive gene expression profiling with the intention to screen for genes involved in response of Arabidopsis cells to genotoxic stress.

Five chemicals belonging to different classes of mutagens (the monofunctional alkylating agents $N$-methyl- $N$-nitrosourea and methyl methanesulfonate, the polyfunctional alkylating agent mitomycin $\mathrm{C}$, the radiomimetic bleomycin and the herbicide maleic hydrazide) were tested. Except for maleic hydrazide, dose-dependent increases in DNA damage were found using the $\mathrm{A} / \mathrm{N}$ comet assay protocol. While a rapid repair of bleomycin-mediated SSBs and DSBs was found, no significant reduction of DNA migration was observed up to $48 \mathrm{~h}$ after treatment with the monofunctional alkylating agents. (C) 2001 Elsevier Science B.V. All rights reserved.
\end{abstract}

Keywords: Arabidopsis thaliana; Comet assay; Monofunctioal alkylating agents; Mitomycin C; Maleic hydrazide; Bleomycin

\section{Introduction}

The comet assay is a suitable technique to measure various types of DNA damage and their repair. DNA damage is quantified by the proportion of DNA which migrates out of the nuclei toward the anode when individual cells or isolated nuclei, embedded in a thin

Abbreviations: A/A, alkaline denaturation and alkaline gel electrophoresis; A/N, alkaline denaturation and neutral gel electrophoresis; DSB, double-strand break; GM, germination medium; MH, maleic hydrazide; MMS, methyl methanesulfonate; MMC, mitomycin C; MNU, $N$-methyl- $N$-nitrosourea; $\mathrm{N} / \mathrm{N}$, neutral gel electrophoresis without prior alkaline denaturation; SSB, single-strand break

${ }^{*}$ Corresponding author. Tel.: +49-39482-5239.

E-mail address: schubert@ipk-gatersleben.de (I. Schubert). agarose layer, are subjected to electrophoresis that results in a "comet-like" shape of nuclei. This enables quantification of DNA in comet tails after staining with an appropriate fluorochrome (e.g. ethidium bromide). The comet assay was first described by Östling and Johanson [1] and numerous modifications have been reported to date [2-4] to allow detection of various types of DNA damage. The modification of the comet assay described by Angelis et al. [5] employs various combinations of neutral and alkali $\mathrm{pH}$ solutions immediately prior and during electrophoresis. Exposure of DNA to high alkali prior to electrophoresis under neutral conditions (A/N protocol) allows for the preferential detection of DNA SSBs. This procedure may result also in the detection of some alkali labile sites depending on the $\mathrm{pH}$ of the alkali unwinding 
solution [6] and the duration of exposure. The majority of alkali labile sites become detectable when electrophoresis is performed in alkaline solution (A/A protocol). DSBs cause comet formation even under completely neutral conditions (N/N protocol). Treatment of DNA after lysis with specific endonucleases can be used for the selective detection of abasic sites or pyrimidine dimers [7].

Since its first application to Vicia faba [8], the comet assay has also been applied to onion [9], tobacco [10], carrot [11], Impatiens balsamina [12] and barley [13].

Here, we describe the application of the comet assay to nuclei of Arabidopsis seedlings. The purpose of these experiments was to evaluate the induction and removal of DNA damage in this plant.

For that purpose, five genotoxic chemicals representative of various classes of mutagens causing different types of DNA lesions (the monofunctional alkylating agents MNU and MMS, the radiomimetic agent bleomycin, the herbicide maleic hydrazide and the multifunctional alkylating agent mitomycin $\mathrm{C}$ ) were selected. The results of these experiments will provide a framework for defining the experimental conditions applicable to the study of gene expression in Arabidopsis thaliana in response to treatments with these classes of genotoxic agents.

\section{Materials and methods}

\subsection{Plant material}

Seeds of A. thaliana (accession Columbia 0) were sterilized in $4 \%$ sodium hypochloride. About $5 \mathrm{mg}$ of seeds were sown in sterile plastic boxes (Magenta Corp., USA) and grown for 9-12 days in $15 \mathrm{ml}$ germination medium (GM, $3.08 \mathrm{~g} / 1$ Gamborg's B-5 Basal salt mixture (Sigma-Aldrich, Steinheim, Germany), B5 Vitamins: $1 \mu \mathrm{g} / \mathrm{ml}$ nicotinic acid, $1 \mu \mathrm{g} / \mathrm{ml}$ pyridoxine $\mathrm{HCl}$ salt, $10 \mu \mathrm{g} / \mathrm{ml}$ thiamine $\mathrm{HCl}$ salt, $100 \mu \mathrm{g} / \mathrm{ml}$ myo-inositol, $0.1 \mathrm{mM}$ Fe-EDTA, $10 \mathrm{~g} / \mathrm{l}$ sucrose, $0.5 \mathrm{~g} / \mathrm{l} \mathrm{MES}, \mathrm{pH} 5.7$ ) on a $2 \mathrm{~cm}$ layer of glass beads $(0.75-1 \mathrm{~mm})$ as solid support. During this time, the plantlets developed cotyledons and reached a size of $5-10 \mathrm{~mm}$. The treatments were done within the same plastic boxes by incubating the plants with the mutagens dissolved in GM. To ensure a correct mutagen concentration, GM was exchanged 3-4 times with the mutagenic solution. To study repair of damage after treatment, the mutagen solution was replaced by mutagen-free GM.

\subsection{Comet assay}

About $75-150 \mathrm{mg}$ of the plant material were harvested, briefly rinsed in GM, carefully dried with a paper towel and then immediately used for the comet assay or frozen in liquid nitrogen and stored at $-80^{\circ} \mathrm{C}$. Freezing and storing did not significantly influence the extent of DNA migration. The comet assay was performed in a darkroom with dim red light. Microscopic slides were precoated with a layer of $1 \%$ normal melting point agarose and thoroughly dried at $60^{\circ} \mathrm{C}$. The seedlings were sliced in 300-400 $\mu \mathrm{l}$ PBS (160 mM NaCl, $8 \mathrm{mM} \mathrm{Na} 2 \mathrm{HPO}_{4}, 4 \mathrm{mM} \mathrm{NaH} \mathrm{PO}_{4}$, $\mathrm{pH}$ 7.0) containing $50 \mathrm{mM}$ EDTA on ice with a fresh razor blade. Two drops of $30 \mu \mathrm{l}$ of the resulting suspension of nuclei were dropped separately on each slide, mixed with the same volume of liquid $1 \%$ low melting point agarose (Gibco BRL, Gaithersburg, USA) at $42^{\circ} \mathrm{C}$ and covered with a $22 \mathrm{~mm} \times 22 \mathrm{~mm}$ coverglass. Nuclei were then either subjected to unwinding in high alkali $(0.3 \mathrm{M} \mathrm{NaOH}, 5 \mathrm{mM}$ EDTA, $\mathrm{pH} 13.5)$ for $10 \mathrm{~min}(\mathrm{~A} / \mathrm{N}$ protocol) or to lysis in high salt $\left(2.5 \mathrm{M} \mathrm{NaCl}_{2}, 10 \mathrm{mM}\right.$ Tris-HCl, pH 7.5, $100 \mathrm{mM}$ EDTA) for $20 \mathrm{~min}$ (N/N protocol) at room temperature. Equilibration for $3 \times 5 \mathrm{~min}$ in $1 \times \mathrm{TBE}(90 \mathrm{mM}$ Tris-borate, 2 mM EDTA, $\mathrm{pH}$ 8.4) buffer on ice was followed by electrophoresis at room temperature in the same buffer for either $4 \mathrm{~min}(\mathrm{~A} / \mathrm{N}$ protocol) or $6 \mathrm{~min}(\mathrm{~N} / \mathrm{N}$ protocol) at $31 \mathrm{~V}(1 \mathrm{~V} / \mathrm{cm}), 15-17 \mathrm{~mA}$. For the A/A comet assay, unwinding was done in high alkali for $5 \mathrm{~min}$ before electrophoresis in the same solution for $10 \mathrm{~min}$ with $21 \mathrm{~V}(0.7 \mathrm{~V} / \mathrm{cm}), 300 \mathrm{~mA}$ in a chamber cooled on ice, followed by a short neutralization step of $3 \mathrm{~min}$ in $100 \mathrm{mM}$ Tris- $\mathrm{HCl}, \mathrm{pH} 7.5$. To clear gels of starch grains that are present in the nuclear suspension, the slides were kept for $10 \mathrm{~min}$ in $1 \%$ Triton prior to dehydration for $2 \times 5 \mathrm{~min}$ in 70 and $96 \%$ ethanol and air-drying.

\subsection{Evaluation of comets}

Dry agarose gels were stained with $15 \mu$ l ethidium bromide $(5 \mu \mathrm{g} / \mathrm{ml}$ dissolved in water), covered with a cover-glass and immediately used for evaluation with 
a Zeiss Axioskop fluorescence microscope (Zeiss, Germany). Images of comets from coded slides were captured at a 20-fold magnification by a monochrome Cohu 4910 CCD camera connected to an IBM-compatible dual PentiumPro computer system. The comet analysis was carried out by the COMET modul of the image analysis software LUCIA (LIM, Prague, CZ). Each experimental point is represented by the mean value ( \pm standard deviation $=$ S.D. $)$ from four comet gels, based on the median values of the percentage of migrated DNA of 35 individual comets per gel. The Student's $t$-test was used to test for significant differences between the groups of medians.

\subsection{Source of mutagens}

Methyl-methanesulfonate (MMS, CAS: 66-27-3) and $N$-methyl- $N$-nitrosourea (MNU, CAS: 684-93-5) were purchased from Sigma-Aldrich (Steinheim, Germany). Mitomycin C (MMC, CAS: 50-07-7), Bleomycin-sulfate (CAS: 9041-93-4) and maleic hydrazide (MH, CAS: 123-33-1) were obtained from Serva (Heidelberg, Germany).

\section{Results and discussion}

\subsection{Technical considerations}

The comet assay was established for Arabidopsis to monitor the genotoxic effects caused by different types of mutagens in cells of 2 weeks old seedlings. Because efficient exchange of media and transfer of plantlets is difficult when seedlings are grown on agar media, glass beads were used as a solid and inert support. This allowed an easy exchange of liquid media and handling of seedlings by tweezers without damaging the plantlets. Although only roots were directly exposed to the mutagens, the induced DNA damage was easily detectable within nuclei prepared from entire seedlings. Plant material in the range of $150 \mathrm{mg}$ (30-50 seedlings) is sufficient for isolation of enough nuclei for the comet analysis per experimental point. To avoid the use of antibiotics or fungicides, all experiments were conducted under sterile conditions. Illumination with dim red light during the preparation of slides improved the consistency and reproducibility of the assay.

\subsection{Monofunctional alkylating agents (MNU, MMS)}

The monofunctional alkylating agents MMS and MNU preferentially induce $N$-alkyl lesions (MMS) or $O$ - and $N$-alkyl lesions (MNU) [14]. Both mutagens cause very efficiently chromatid type chromosomal aberrations and sister chromatid exchanges in $V$. faba; doses of 1-2 mM MNU and 2.5-5 mM MMS, respectively, yielded up to $48 \%$ of first post-treatment metaphases with structural aberrations in root meristems [15]. Because of its small chromosomes it is nearly impossible to determine the frequency of chromosomal aberrations and sister chromatid exchanges in Arabidopsis. However, scoring for the induction of micronuclei is feasible. After treatment of Arabidopsis seedlings with $1 \mathrm{mM}$ MNU for $1 \mathrm{~h}$, recovery for 9, 12,18 and $30 \mathrm{~h}$ and counting of 500 cells per experimental point from squashed root tip preparations, the proportion of cells with micronuclei was $0.1 \%$ (controls: $0.4 \%$ ), while the proportion of cells in meta-, ana- and telophases averaged $1.5 \%$, as compared to $1.2 \%$ in the controls. Bridges or fragments were not observed in mitotic cells. After treatment with $5 \mathrm{mM}$ $\mathrm{MNU}$ for $2 \mathrm{~h}$ followed by 18 or $36 \mathrm{~h}$ of recovery, neither cells with micronuclei nor mitotic cells were found among 1000 cells scored per recovery time. In this experiment, the control values for 1000 untreated cells were $0.2 \%$ with micronuclei and $2 \%$ of cells in meta-, ana- and telophases (Schubert, unpublished result). According to these preliminary results, neither the micronucleus test nor the anaphase test seem to be appropriate for genotoxicity testing in Arabidopsis seedlings. Therefore, we decided to evaluate the comet assay as a sensitive technique for detection of induced DNA damage. For this purpose, nuclei from entire seedlings were tested for comet formation after $2 \mathrm{~h}$ of mutagen treatment using two different comet protocols. MNU and MMS caused a nearly linear increase in DNA migration at a dose range between 1 and $10 \mathrm{mM}$ when the $\mathrm{A} / \mathrm{N}$ protocol for detection of SSBs and DSBs was applied (Fig. 1). Using the N/N protocol (without any alkali treatment) for the detection of DBSs only [4], no significant increase in DNA migration was observed (Fig. 1). The data obtained with both protocols correspond well with data previously obtained for MNU in V. faba nuclei [16]. This confirms that alkylating agents do not directly induce DSBs. Since the increase of the dose-response curve for MNU 


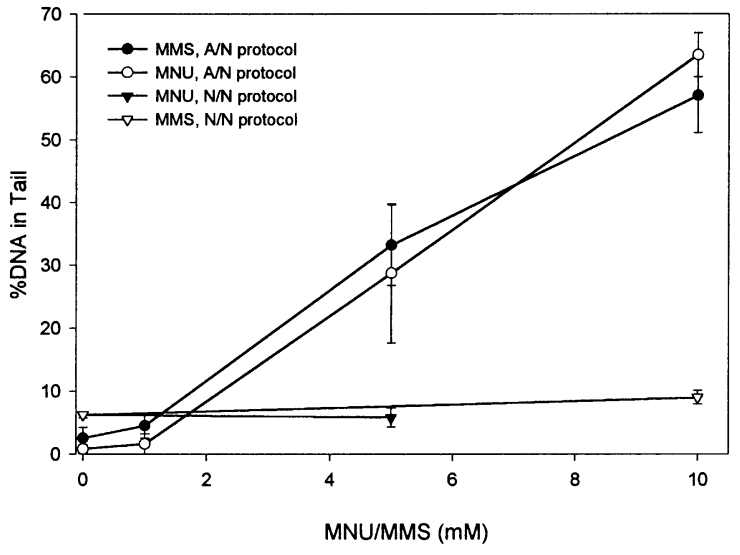

Fig. 1. Mean percentage of DNA in tail (mean of the medians from four individual gels per experimental point \pm standard deviation = S.D.) after treatment with MNU or MMS and performance of the comet assay according to the $\mathrm{A} / \mathrm{N}$ or the $\mathrm{N} / \mathrm{N}$ protocol.

was significantly higher in the $\mathrm{A} / \mathrm{A}$ than in the $\mathrm{A} / \mathrm{N}$ assay [16], we conclude that the $\mathrm{A} / \mathrm{N}$ protocol detects mainly repair-mediated SSBs while most of the alkali labile sites were detected only with the A/A protocol.

To investigate repair kinetics after treatment with MNU and MMS, the mutagenic solutions were exchanged for GM. The plants were then allowed to recover for up to $48 \mathrm{~h}$ before nuclei were processed according to the $\mathrm{A} / \mathrm{N}$ comet assay. Compared to the initial increase in DNA migration following treatment, only a weak (5 mM MNU/MMS) or no reduction of DNA migration (1 mM MNU) was observed. In no case, were the negative control values reached (Fig. 2). Similar data have been reported for tobacco leaves and roots after EMS treatment [17]. Even 4 weeks after treatment, these authors did not observe a significant reduction in DNA migration when using the A/A comet assay protocol. Using alkaline sucrose centrifugation ( $\mathrm{pH}>13$ ), an accumulation of MNU-induced damage expressed as SSBs was found in embryos of $V$. faba [18] and barley [19] during a post-treatment cultivation of 20 and $18 \mathrm{~h}$, respectively. Contrary to the situation in plants, the alkylation damage detected by the comet assay in cultured mammalian cells was found to

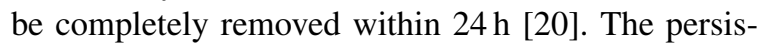
tence of alkylation-mediated DNA damage in plants is usually ascribed to a low capacity for repair and/or slow repair progress, particularly in differentiated

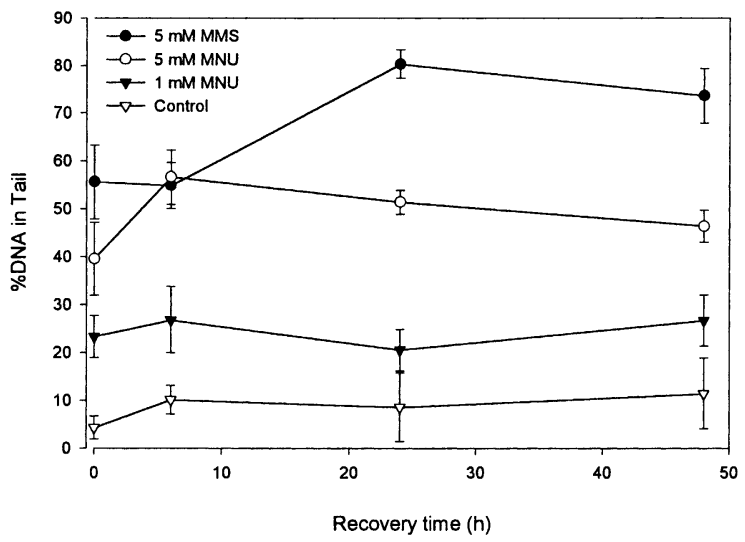

Fig. 2. Mean percentage of DNA in tail ( \pm S.D.) at various recovery times after treatment with MNU or MMS and performance of the comet assay according to the A/N protocol.

nondividing cells [17]. In barley, after treatment with 0.1-10 mM MNU followed by recovery for up to $48 \mathrm{~h}$, the extent of MNU-induced DNA migration was not significantly decreased in leaf cells, but was for meristematic cells of the root tips [13]. In this study, the A/N comet assay protocol was used. Furthermore, it was shown that adaptation to genotoxic treatments, similar to the phenomenon of clastogenic adaptation [21], can be monitored in $V$. faba root tips by the comet assay [7]. During adaptation, AP sites were induced, indicating that at least part of the alkyl lesions caused by MMS and MNU were removed by base excision repair.

The meristematic cells of Arabidopsis seedlings represent only a minor cell fraction. Therefore, it seems likely that a repair of alkylation damage in dividing cells is masked in our experiments. The lack of (complete) repair in differentiated plant tissues suggest that at least sealing of breaks seems to be delayed in these cells.

\subsection{The radiomimetic bleomycin}

Bleomycin induces directly SSBs and DSBs [22] and was shown to be clastogenic in $V$. faba $(1 \mu \mathrm{g} / \mathrm{ml}$ caused up to $30 \%$ of metaphases with chromosomal aberrations immediately after treatment [21]). In our experiments, Arabidopsis seedlings were incubated for $1 \mathrm{~h}$ with doses ranging from 0.25 to $1 \mu \mathrm{g} / \mathrm{ml}$. With the N/N assay, we observed a linear dose-dependent increase in DNA migration with up to $35 \%$ of the 


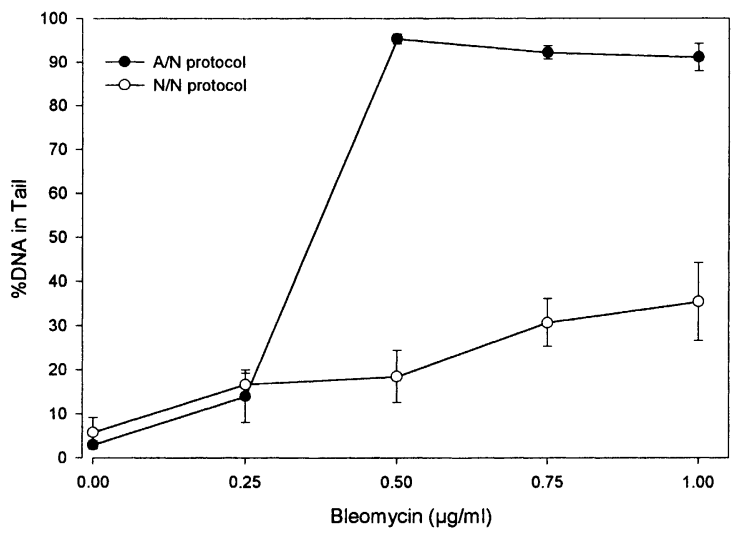

Fig. 3. Mean percentage of DNA in tail ( \pm S.D.) after treatment with different doses of bleomycin and performance of the comet assay according to the $\mathrm{A} / \mathrm{N}$ or the $\mathrm{N} / \mathrm{N}$ protocol.

DNA in the tail at $1 \mu \mathrm{g} / \mathrm{ml}$. In contrast, using the A/N comet assay protocol, nearly all of the DNA had migrated into the tail at a dose level of $0.5 \mu \mathrm{g} / \mathrm{ml}$ (Fig. 3). Contrary to alkylation damage, DSBs and SSBs induced by a $1 \mathrm{~h}$ treatment with $1 \mu \mathrm{g} / \mathrm{ml}$ bleomycin were completely removed from the DNA of Arabidopsis seedlings within $1 \mathrm{~h}$ of recovery (Fig. 4). During this period of time, DNA migration measured by the $\mathrm{A} / \mathrm{N}$ comet assay protocol dropped from the initial level of $98.7 \%$ DNA in the tail to $9.9 \%$ (not significantly above the control value of $8.5 \%$, $P=0.3)$. A very efficient repair of bleomycin- or

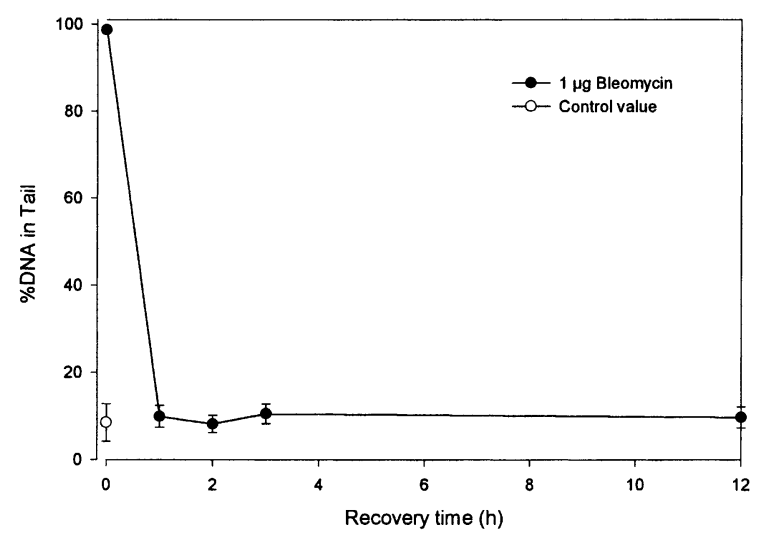

Fig. 4. Mean percentage of DNA in tail ( \pm S.D.) at various recovery times after treatment with $1 \mu \mathrm{g} / \mathrm{ml}$ bleomycin and performance of the comet assay according to the $\mathrm{A} / \mathrm{N}$ protocol.
X-ray-induced DNA breaks was previously reported for $V$. faba $[23,24]$ as well as for mammalian cells (for review see [25]). Bleomycin-induced DNA damage appears to be repaired mainly by rapid end joining in both plants and in mammals [26,27], while repair of alkylation damage depends on other mechanisms of DNA repair.

\subsection{The uracil analogue maleic hydrazide}

Maleic hydrazide (MH) is a plant growth regulator and herbicide. In contrast to the situation in other plants, MH is not mutagenic in A. thaliana [28]. In $V$. faba, root meristems treatment with $\mathrm{MH}$ doses in the range of $4-16 \mathrm{mM}$ for $0.5 \mathrm{~h}$ at $\mathrm{pH} 5.4$ caused $35-80 \%$ of metaphases with aberrations [29]. To investigate whether or not MH induces DNA damage in Arabidopsis, seedlings were treated for $1 \mathrm{~h}$ with $0.4-8 \mathrm{mM}$ of $\mathrm{MH}$ in $\mathrm{GM}$ at $\mathrm{pH}$ 5.7. Using the $\mathrm{A} / \mathrm{N}$ protocol for the comet assay, no DNA damage above the control values was detected. Applying the A/A protocol, three doses caused significantly increased DNA migration above the control, however, the response was not dose-dependent (Fig. 5). No significant increase in DNA migration after treatment with the same $\mathrm{MH}$ doses was observed in tobacco and $V$. faba nuclei using the A/A protocol for the comet assay, although this treatment induced mutations and chromatid aberration, respectively [30].

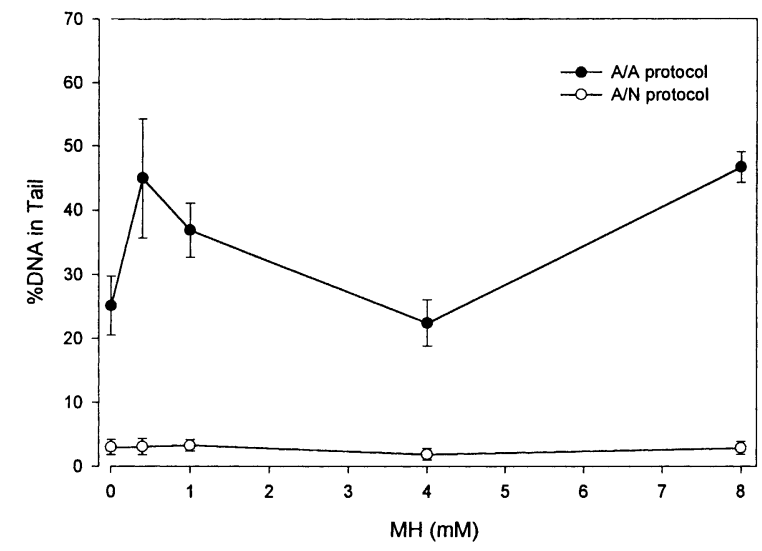

Fig. 5. Mean percentage of DNA in tail $( \pm$ S.D. $)$ after treatment with maleic hydrazide $(\mathrm{MH})$ and performance of the comet assay according to the $\mathrm{A} / \mathrm{N}$ or the $\mathrm{A} / \mathrm{A}$ protocol. 


\subsection{The cross-linking alkylating agent mitomycin $C$}

The multifunctional alkylating agent mitomycin $\mathrm{C}$ (MMC) induces DNA-DNA cross-links. Cross-links can be detected using the comet assay via inhibition of DNA migration when cross-linking agents are applied after X-irradiation or treatment with other DNA damaging agents and alkaline denaturation is performed (for review see [31]). We used $5 \mathrm{mM}$ MNU to induce substantial DNA damage in Arabidopsis seedlings and applied different concentrations of MMC simultaneously with MNU for $1 \mathrm{~h}$ to induce DNA cross-links. Using the $\mathrm{A} / \mathrm{N}$ protocol for the comet assay, treatment with MNU alone revealed about $40 \%$ of the DNA in the tail while the additional presence of MMC led to a dose-dependent decrease of DNA migration. At a concentration of $500 \mu \mathrm{M}$ MMC very few nuclei with tails were present. A reduced comet formation after MMC treatment of mammalian cells was found only at doses which were cytotoxic [3]. In Arabidopsis, weakly reduced comet formation was found after additional treatment with $10 \mu \mathrm{M}$ MMC, a dose that induced chromatid aberrations in about $38 \%$ of first post-treatment mitoses in $V$. faba [32]. Significant effects ( $t$-test, $P<0.01$ ) were observed only with doses of $50 \mu \mathrm{M}$ and higher (Fig. 6) which proved to be lethal to Arabidopsis seedlings after 10 days when applied continuously.

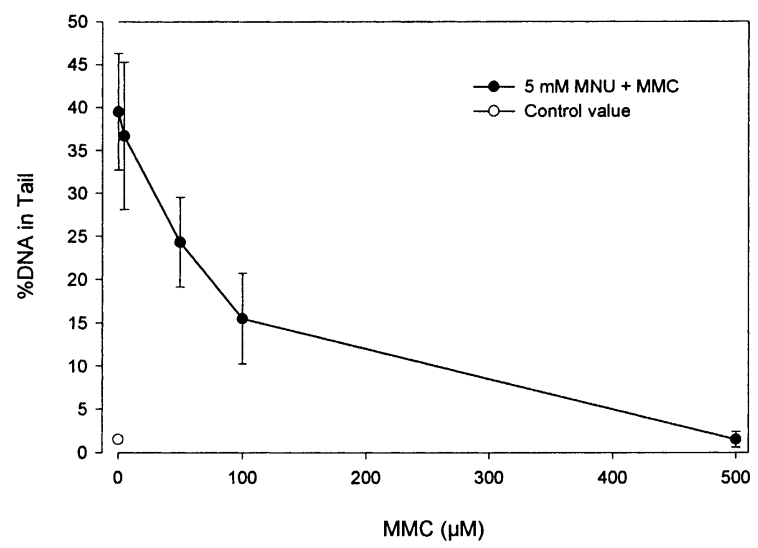

Fig. 6. Mean percentage of DNA in tail $( \pm$ S.D.) after treatment with $5 \mathrm{mM} \mathrm{MNU}$ together with various concentrations of mitomycin $\mathrm{C}$ (MMC) and performance of the comet assay according to the $\mathrm{A} / \mathrm{N}$ protocol.

\section{Conclusions and prospects}

The presented data show that DNA damage caused by various genotoxins in Arabidopsis can be detected when suitable comet protocols are used. The experimental conditions under which the tested compounds induce detectable DNA damage in Arabidopsis nuclei were similar to those causing genotoxic effects in other plants as measured by either the comet assay or other tests. Since we expect that these conditions will elicit the up- or down-regulation of genes involved in the response to genotoxic stress, gene expression profiling will show which known (and hitherto unknown) genes contribute to mutagenesis, DNA repair and recombination in plants after exposure to different types of genotoxins. From the functional analyses of gene expression, informations on the mechanisms of DNA damage processing will be obtained. In addition, we expect answers to the following questions: (i) What is the reason for the fast repair of bleomycin-induced breaks versus the slow repair of damage mediated by monfunctional alkylating agents? (ii) To what extent does maleic hydrazide modulate the expression of the same genes modulated by substances which are clearly genotoxic in Arabidopsis?

\section{Acknowledgements}

We thank Martina Kühne, Barbara Hildebrandt and Christa Fricke for excellent technical assistance and Rigomar Rieger and Holger Puchta for critical reading of the manuscript. This work was supported by a grant from the Deutsche Forschungsgemeinschaft (Schu 951/5-3) and a grant (521/01/1418) from the Grant Agency of the Czech Republic.

\section{References}

[1] O. Östling, K.J. Johanson, Microelectrophoretic study of radiation-induced DNA damages in individual mammalian cells, Biochem. Biophys. Res. Commun. 123 (1984) 291-298.

[2] D.W. Fairbairn, P.L. Olive, K.L. O'Neill, The comet assay: a comprehensive review, Mutat. Res. 339 (1995) 37-59.

[3] O. Merk, G. Speit, Detection of cross-links with the comet assay in relationship to genotoxicity and cytotoxicity, Environ. Mol. Mutagen. 33 (1999) 167-172. 
[4] M. Menke, K.J. Angelis, I. Schubert, Detection of specific DNA lesions by a combination of comet assay and FISH in plants, Environ. Mol. Mutagen. 35 (2000) 132-138.

[5] K.J. Angelis, M. Dusinská, A.R. Collins, Single cell gel electrophoresis: detection of DNA damage at different levels of sensitivity, Electrophoresis 20 (1999) 2133-2138.

[6] J.E. Yendle, H. Tinwell, B.M. Elliott, J. Ashby, The genetic toxicity of time: importance of DNA-unwinding time to the outcome of single-cell gel electrophoresis, Mutat. Res. 375 (1997) 125-136.

[7] K.J. Angelis, M. McGuffie, M. Menke, I. Schubert, Adaptation to alkylation damage in DNA measured by the comet assay, Environ. Mol. Mutagen. 36 (2000) 146-150.

[8] G. Koppen, L. Verschaeve, The alkaline comet test on plant cells: a new genotoxicity test for DNA strand breaks in Vicia faba root cells, Mutat. Res. 360 (1996) 193-200.

[9] M.H. Navarrete, P. Carrera, M. de Miguel, C. de la Torre, A fast comet assay variant for solid tissue cells: the assessment of DNA damage in higher plants, Mutat. Res. 389 (1997) 271-277.

[10] T. Gichner, M.J. Plewa, Induction of somatic DNA damage as measurable by single cell gel electrophoresis and point mutation in leaves of tobacco plants, Mutat. Res. 401 (1998) $143-152$.

[11] X.-F. Jiang, Z. Hai-Zhen, Z. Jun, C. Hao-Ming, D. Yao-Ren, Application of the comet assay in plant protoplast apoptosis detection, Acta Bot. Sin. 40 (1998) 928-932.

[12] P. Poli, A. Buschini, A. Ficarelli, F.M. Restivo, T.M.A.D. Zucci, C. Rossi, The comet assay applied to micro-organisms and plants: methods and problems, Neoplasma 46 (1999) 76-78.

[13] G. Jovtchev, M. Menke, I. Schubert, The comet assay detects adaption to MNU-induced DNA damage in barley, Mutat. Res. 493 (2001) 97-102.

[14] P.J. O'Connor, Studies on mechanism of action-interaction of chemical carcinogens with macromolecules, J. Cancer Res. Clin. Oncol. 99 (1981) 167-186.

[15] I. Schubert, R. Rieger, Effects of hydroxyurea post-treatment in $\mathrm{G} 2$ on the frequency and distribution of mutagen-induced chromatid aberrations in a reconstructed karyotype of Vicia faba, Biol. Zbl. 106 (1987) 59-66.

[16] M. Menke, A. Meister, I. Schubert, $N$-methyl- $N$-nitrosoureainduced DNA damage detected by the comet assay in Vicia faba nuclei during all interphase stages is not restricted to chromatid aberration hot spots, Mutagenesis 15 (2000) 503-506

[17] T. Gichner, O. Ptácek, D.A. Stavreva, E. Wagner, A comparison of DNA repair using the comet assay in tobacco seedlings after exposure to alkylating agents and ionizing radiation, Mutat. Res. 470 (2000) 1-9.

[18] K.J. Angelis, J. Veleminský, R. Rieger, K. Heindorff, Interaction of maleic hydrazide or $N$-methyl- $N$-nitrosourea with root tip DNA of in vitro cultured Vicia faba embryos, Biol Zbl. 105 (1986) 29-36.

[19] J. Veleminský, V. Pokorný, J. Satava, T. Gichner, Postreplication DNA repair in barley embryos treated with $N$-methyl- $N$-nitrosourea, Mutat. Res. 71 (1980) 91-99.

[20] P. Fortini, G. Raspaglio, M. Falchi, E. Dogliotti, Analysis of DNA alkylation damage and repair in mammalian cells by the comet assay, Mutagenesis 11 (1996) 169-175.

[21] K. Heindorff, I. Schubert, R. Rieger, A. Michaelis, Clastogenic adaptation of Vicia faba root tip meristem cells after consecutive treatments with S-phase-dependent and S-phase independent agents, Biol. Zbl. 106 (1987) 439-448.

[22] V. Favaudon, On the mechanism of reductive activation in the mode of action of some anticancer drugs, Biochimie 64 (1982) 209-218.

[23] K.J. Angelis, J. Veleminsky, R. Rieger, I. Schubert, Repair of bleomycin-induced DNA double-strand breaks in Vicia faba, Mutat. Res. 212 (1989) 155-157.

[24] G. Koppen, K.J. Angelis, Repair of X-ray-induced DNA damage measured by the comet assay in roots of Vicia faba, Environ. Mol. Mutagen. 32 (1998) 281-285.

[25] R. Tice, The single cell gel/comet assay: a microgel electrophoretic technique for the detection of DNA damage and repair in individual cells, in: D.H. Phillips, S. Venitt (Eds.), Enviromental Mutagenesis, bios Scientific Publishers, Oxford, 1995, pp. 315-339.

[26] A.B. Britt, DNA damage and repair in plants, Ann. Rev. Plant Physiol. Plant Molecular Biol. 47 (1996) 75-100.

[27] P. Pfeiffer, B. Göttlich, S. Reichenberger, E. Feldmann, P. Daza, J.F. Ward, J.R. Milligan, L.H. Mullenders, A.T. Natarajan, DNA lesions and repair, Mutat. Res. 366 (1996) 69-80.

[28] T. Gichner, S.A. Badayev, S.I. Demchenko, S. Relichová, S. Sandhu, P.D. Usmanov, O. Usmanova, J. Veleminsky, Arabidopsis assay for mutagenesis, Mutat. Res. 310 (1994) 249-256.

[29] K. Heindorff, R. Rieger, Exogenous factors affecting yield and intrachromosomal distribution of maleic hydrazide-induced chromatid aberrations in Vicia faba, Biol. Zbl. 103 (1984) 9-23.

[30] T. Gichner, M. Menke, D.A. Stavreva, I. Schubert, Maleic hydrazide induces genotoxic effects but no DNA damage detectable by the comet assay in tobacco and field bean, Mutagenesis 15 (2000) 385-389.

[31] G. Speit, O. Merk, Detection of cross-links with the comet assay, Neoplasma 46 (1999) 76-78.

[32] I. Schubert, S. Sturelid, P. Döbel, R. Rieger, Intrachromosomal distribution patterns of mutagen-induced SCEs and chromatid aberrations in reconstructed karyotypes of Vicia faba, Mutat. Res. 59 (1979) 27-38. 